\title{
LOGO COLOUR, EARNINGS MANAGEMENT AND FIRM VALUE
}

\section{Tao Chen*}

\begin{abstract}
I document a new channel that can be used by managers who can take advantage of investors preference for logo colours to influence their perception of the financial reports and thus indirectly affect firm value. Evidence suggests that firms having warm colours as a major logo colour, fewer colours used in the logo, and recognizable elements in the logo are associated with lower earnings management and higher firm value. My findings remain stable across different robustness checks.
\end{abstract}

Keywords: logo, colour, earnings management, firm value JEL Classification: G02, G32, M41

\section{Introduction}

Impression management is described as the conscious or unconscious attempt to control images that are projected in real or imaginary social interactions. Several prior studies apply this concept to prove how firms obtain endorsement and support from stakeholders (Elsbach and Sutton, 1992; Clatworthy and Jones, 2003). Impression management is thus in line with the obfuscation hypothesis, which is based on the attitudes of managers who obfuscate failures and stress successes. Merkl-Davies and Brennan (2007) attribute theoretical foundations of such hypothesis to theories focussed on agency (Abrahamson and Amir, 1996), signalling (Smith and Taffler, 1992), legitimacy (Ogden and Clarke, 2005), stakeholder (Hooghiemstra, 2000), and institutional theory (Bansal and Clelland, 2004). Obviously, these theories together indicate that impression management is an intentional reporting strategy.

Similarly, impression management is also deeply rooted in financial reporting whereby managers deliberately choose information, language, and pictures to present it in a way that distorts financial statement users' understanding of corporate achievement (Osma and Guillamon-Saorin, 2011). In this paper, I concentrate on one sort of impression management: visual rhetoric. It is a process in which the sender of a message (manager) is trying to use various visual options such as picture, word, or colour to attain the desired effect on the receivers (investors). As a result, it is strongly believed that visual rhetoric does convey information which affects investors' behaviour (Courtis, 2004).

A number of prior studies (Muino and Trombetta, 2009) examine how visual rhetoric can influence investors by using pictures as a complementary tool instead of only using plain word. Colour itself seldom enters the eyesight of accounting and finance scholars.

* Lee Shau Kee School of Business and Administration, Open University of Hong Kong, Homantin, Kowloon, Hong Kong (tchen@ouhk.edu.hk).

The author is grateful for financial support from the Open University of Hong Kong School Research Grant (Project No. R2046-0). All errors remain my own responsibility. 
Nevertheless, there is an emerging strand of literature in the marketing area (Chebat and Morrin, 2007) suggesting that affective colour can lead to desirable marketing outcome. This group of literature suggests that colour serves as a signalling tool to convey information beyond the substance of words and numbers.

I argue that colour is an integral element of our life so that it widely appears in our environment. As a compelling visual cue for persuasive communication purpose, different colours may be interpreted as different symbols such as warmth or coolness, nervousness or relaxation, and security or danger. In the context of financial reporting, information can be prioritized by presenting with different colors. Through skillfully employing colour, managers direct (derail) investor attention to the information favourable (detrimental) to the company. If done appropriately, investors are tempted easily to establish a perception about a company's sound and health prospect.

Over the past half-century, although the presence of colour is likely to alter moods and hence, influence behaviour, the specific role that colour plays in the investors' perceptions seems unexplored in the realm of corporate reporting. The objective of this study is to examine a new channel by which colour may be manipulated by managers to affect the process of asset pricing in the capital market. Specifically, I study whether logo colours appearing on the front page of the annual report matters to earnings management and firm valuation. The findings suggest that companies with warm and simple logo colours would attract more focus from investors and therefore reduce the incidence of earnings management which is consistent with impression management. In addition, firms with warm and simple logo indicate that they have significantly higher valuation. This is consistent with my argument of excess demand for these firms' stocks. As long as it is true that demand curves for stocks slope down (Shleifer, 1986), then these distinctions in demand could cause an increases in firm valuation. Taken together, firms with warm and simple logo colours have a low level of earnings management and a higher firm value.

The remainder of the paper is organized as follows. The following section reviews the previous studies and develops the hypotheses. Section 3 describes the data and methods used to verify my prediction. Section 4 discusses the effect of logo colours on earnings management and firm value. Robustness checks are performed in Section 5, and Section 6 concludes.

\section{Hypothesis Development}

By definition, the goal of impression management is to manipulate the image the third parties have of them (Leary, Kowalski, 1990). As outsiders, investors have to rely on information prepared by managers to evaluate the management performance (Lambert, 2001). Therefore, managers, due to their self-interests of looking good in order to get private benefits, are motivated to use tools that can bias investors' perception about financial reports to downplay negative news and to highlight positive news (Schrand, Walther, 2000; Bowen, Davis, Matsumoto, 2005; Krische, 2005). Impression management, such as logo colour, is a convenient tool for managers trying to bias investors' perception. In the agency theory perspective, impression management is a result of divergence interests between shareholders and managers.

Most firms would like to show the firm logo on the front page of their annual reports. It seems that logo colours do not provide incremental information, but colours indeed trigger 
favourable judgment. In addition, Benbasat, Dexter $(1985,1986)$ find that colours help users of financial statements to make informed decision. In general, Coutis (2004) discusses several rationales to apply colour strategically. First, colours may save user's time effectively by rendering the communication vehicle more appealing. Second, colours may direct the analytical attention of users by emphasizing important information. Lastly, colours may shift user's focus away from negative information by neglecting weak performance that shows management in a poor light.

This study evaluates the colour effect in two dimensions, namely, warm/cool colour and "colour fluency". According to recent marketing research, cool and warm colours can be translated into different meanings to consumers (Chebat, Morrin, 2007). Typically, while cold colours represent to be peaceful, gentle, and calming, warm colours are interpreted to be emotional, vibrant, hot, active, sharp, and stimulating (Madden, Hewett, Roth, 2000). Based on the conceptual arguments developed in this literature, warm logo colours on the first page of financial statements can persuade investors to devote more time to looking through the whole document. This, in turn, should be associated with high-quality earnings information and reduces managerial opportunities to engage in earnings management. While it is plausible that several colours appear in one logo, I gauge warm/cool colour through the primary colour inside the logo. The first hypothesis is:

$\mathbf{H}_{1}$ : Warm logo colour, proxied by the primary colour inside the logo, is associated with lower earnings management.

Consistent with the reasoning that firms with warm logo colours are easier to attract investors, I further argue that firms with warm logo colours induce excess demand for their stocks and therefore bring higher firm valuation. In addition, the effects of warm colours on earnings management may generate important implications for firm valuation. For instance, Chaney, Lewis (1995) show that earnings management affects firm valuation in an opposite direction when value-maximizing managers and investors are asymmetrically informed. Subsequently, the second hypothesis is developed:

$\mathbf{H}_{2}$ : Warm logo colour, proxied by the primary colour inside the logo, is associated with higher firm value.

Another measure to capture the logo colour effect is "colour fluency". This is inspired by Bottomley, Doyle (2006) who suggest perceptual fluency as the ease with which a stimulus is processed has an impact on decision making. Practically, people intuitively feel more comfortable and tend to spend more effort reading financial reports if fewer colours and simple images are used inside the logo. Green, Jame (2013) suggest that investors are drawn to firms with short, simple, easy, and fluent names. Along these lines, I contend that firms with logos that are easy to be mentally processed would experience lower levels of earnings management and higher firm value. These hypotheses are stated as:

$\mathbf{H}_{3}$ : Fewer colours inside the logo are related to lower earnings management and higher firm value.

$\mathbf{H}_{4}$ : Simpler image inside the logo is related to lower earnings management and higher firm value. 


\section{Sample and Methodology}

\subsection{Sample selection}

I start the sample selection process by manually collecting the logos from annual reports for all firms listed in Hong Kong from 2000 to 2011. As shown in Table 1, the number of samples that have logos in their annual reports increases from 155 in 2000 to 1,420 in 2011. The percentage of these firms using logos reveals a dramatic rising trend from only $34.8 \%(155 / 446)$ in 2000 to $98.5 \%(1420 / 1442)$ in 2011. Next, I search Datastream for financial data to estimate the performance-adjusted current discretionary accruals (PACDA) and discretionary component of accrual quality (Disc_AQ), two measures of earnings management. Other control variables are also extracted from Datastream. Table 1 reports the number of sample each year and its distribution.

\subsection{Measures of colour effects}

In this study, I try to capture the colour effect along two dimensions by constructing three dummy variables. First, I reason that companies with warm logo colour are less likely to engage in earnings management and therefore lead to a higher firm valuation. In order to measure the type of colours, I follow Chebat, Morrin (2007) to categorized colours along warm (brown, orange, purple, red, and yellow) and cool (blue, green, and grey) continuum. Because it is possible for one logo to contain several colours, I just focus on the major colour used inside the logo. If the major logo colour is warm, the dummy variable, Colour, is assigned to 1 , otherwise 0 .

Research in psychology indicates that the ease with which a stimulus is processed is related to decision making. To operationalize this idea, I additionally examine two other measures of colour effects relevant to colour fluency, namely, the number of colours and the degree of image complexity. If there is only one logo colour, the dummy variable, Number, is equal to 1 , otherwise 0 . In terms of the degree of image complexity, I believe that logos with characters or numbers are likely to be more recognizable on average than those with only pictures. In this sense, a dummy variable Simple is equal to 1 if there are any characters or numbers inside the logo.

As seen in Table 1, companies prefer to use warm colours rather than cool colours in their logos. Specifically, red is the most favourable colour used to design the logo, followed by blue. Meanwhile, the number of firms which choose one colour to design the logo is twice as many as firms with more than one colour. However, managers are inclined to use a complex logo where any meaningful numbers or characters are not shown up in the logo.

\subsection{Measures of earnings management and firm value}

To gauge earnings management, I follow two populous methods in recent literature (Jaggi, Leung, Gul, 2009). The first proxy is the performance-adjusted current discretionary accruals $(P A C D A)$. As suggested by Kothari, Leone, Wasley (2005), firm performance should be considered in calculating discretionary accruals. I estimate Equation 1 below separately for each combination of industry classification code and year (minimum of 10 firms) to obtain the industry-specific parameters for calculation of expected current accruals. 
Table 1 | Sample by Colour and Year

\begin{tabular}{|c|c|c|c|c|c|c|c|c|c|c|c|c|}
\hline & 2000 & 2001 & 2002 & 2003 & 2004 & 2005 & 2006 & 2007 & 2008 & 2009 & 2010 & 2011 \\
\hline Primary sample & 446 & 634 & 854 & 977 & 1,094 & 1,174 & 1,206 & 1,267 & 1,347 & 1,416 & 1,441 & 1,442 \\
\hline Sample with logo & 155 & 344 & 490 & 587 & 673 & 789 & 960 & 1,101 & 1,147 & 1,218 & 1,329 & 1,420 \\
\hline \multicolumn{13}{|l|}{ By major colours } \\
\hline Cold & 69 & 170 & 222 & 281 & 336 & 389 & 478 & 527 & 557 & 583 & 645 & 694 \\
\hline Blue & 33 & 77 & 104 & 133 & 163 & 200 & 254 & 274 & 287 & 307 & 353 & 383 \\
\hline Green & 11 & 29 & 43 & 60 & 61 & 86 & 95 & 113 & 131 & 135 & 143 & 154 \\
\hline Grey & 25 & 64 & 75 & 88 & 112 & 103 & 129 & 140 & 139 & 141 & 149 & 157 \\
\hline Warm & 86 & 174 & 268 & 306 & 337 & 400 & 482 & 574 & 590 & 635 & 684 & 726 \\
\hline Brown & 16 & 23 & 56 & 66 & 62 & 91 & 113 & 143 & 134 & 138 & 144 & 153 \\
\hline Orange & 6 & 14 & 13 & 15 & 19 & 21 & 30 & 30 & 30 & 33 & 31 & 35 \\
\hline Purple & 2 & 4 & 9 & 11 & 13 & 13 & 14 & 19 & 17 & 21 & 21 & 18 \\
\hline Red & 46 & 105 & 137 & 172 & 199 & 227 & 271 & 323 & 341 & 367 & 406 & 432 \\
\hline Yellow & 16 & 28 & 53 & 42 & 44 & 48 & 54 & 59 & 68 & 76 & 82 & 88 \\
\hline \multicolumn{13}{|c|}{ By number of colours } \\
\hline One & 108 & 235 & 311 & 380 & 428 & 490 & 609 & 704 & 725 & 762 & 829 & 892 \\
\hline Two and more & 45 & 110 & 176 & 210 & 246 & 299 & 350 & 396 & 422 & 456 & 500 & 529 \\
\hline \multicolumn{13}{|l|}{ By simplicity } \\
\hline Simple & 56 & 132 & 187 & 224 & 260 & 299 & 370 & 427 & 434 & 464 & 503 & 561 \\
\hline Complex & 98 & 214 & 301 & 366 & 415 & 490 & 588 & 674 & 713 & 754 & 826 & 859 \\
\hline
\end{tabular}

Note: Table 1 reports the total number of primary sample and the distribution for sample with logo based on major colours, number of colours, and simplicity. Primary sample includes all common stocks with available financial data in Datastream, and spans from 2000-2011. The sample employed in this study is just restricted to firms with logo. Major colours of the company's logo are categorized along a warm (brown, orange, purple, red, and yellow) and cool (blue, green, and grey) continuum in light of Chebat, Morrin (2007). Samples are divided into two groups based on the number of colours in the company logo. First Group (Two and above) represents the logo with one (two and more) colours. Samples are assigned into the Simple group if character or number appears inside the logo.

$$
\frac{\mathrm{TCA}_{\mathrm{i}, \mathrm{t}}}{\mathrm{AT}_{\mathrm{i}, \mathrm{t}-1}}=\alpha_{0} \frac{1}{\mathrm{AT}_{\mathrm{i}, \mathrm{t}-1}}+\alpha_{1} \frac{\Delta \mathrm{Sale}_{\mathrm{i}, \mathrm{t}}}{\mathrm{AT}_{\mathrm{i}, \mathrm{t}-1}}+\alpha_{2} \mathrm{ROA}_{\mathrm{i}, \mathrm{t}-1}+\varepsilon_{\mathrm{i}, \mathrm{t}}
$$

Where $T C A_{i, t}$ is the total current accruals calculated by net income plus depreciation and amortization minus operating cash flows. $\triangle$ Sale $e_{i, t}$ is the change in sales. $R O A_{i, t}$ is the return on assets. $A T_{i, t}$ is the total assets. I calculate the expected current accruals using the parameters in Equation 1 as follows: 


$$
\frac{\mathrm{ECA}_{\mathrm{i}, \mathrm{t}}}{\mathrm{AT}_{\mathrm{i}, \mathrm{t}-1}}=\alpha_{0} \frac{1}{\mathrm{AT}_{\mathrm{i}, \mathrm{t}-1}}+\alpha_{1}\left(\frac{\Delta \mathrm{Sale}_{\mathrm{i}, \mathrm{t}}-\Delta \mathrm{AR}_{\mathrm{i}, \mathrm{t}}}{\mathrm{AT}_{\mathrm{i}, \mathrm{t}-1}}\right)+\alpha_{2} \mathrm{ROA}_{\mathrm{i}, \mathrm{t}-1}
$$

Where $\triangle A R_{i, t}$ is the change in account receivables. Finally, $P A C D A$ can be defined as the absolute value of unexpected current accruals $\left(U C A_{i, t}\right)$.

$$
\operatorname{PACDA}=\left|\frac{\mathrm{UCA}_{i, t}}{\mathrm{AT}_{\mathrm{i}, \mathrm{t}-1}}\right|=\left|\frac{\mathrm{TCA}_{\mathrm{i}, \mathrm{t}}}{\mathrm{AT}_{\mathrm{i}, \mathrm{t}-1}}-\frac{\mathrm{ECA}_{\mathrm{i}, \mathrm{t}}}{\mathrm{AT}_{\mathrm{i}, \mathrm{t}-1}}\right|
$$

The second measure for earnings management is the discretionary component of accrual quality (Disc_AQ). This measure is effective in overcoming measurement errors to estimate discretionary accruals (Francis, LaFond, Olsson, Schipper, 2005). Firstly, I estimate the below model:

$$
\mathrm{TCA}_{\mathrm{i}, \mathrm{t}}=\alpha_{0}+\alpha_{1} \mathrm{CFO}_{\mathrm{i}, \mathrm{t}-1}+\alpha_{2} \mathrm{CFO}_{\mathrm{i}, \mathrm{t}}+\alpha_{3} \mathrm{CFO}_{\mathrm{i}, \mathrm{t}+1}+\alpha_{4} \Delta \mathrm{Sale}_{\mathrm{i}, \mathrm{t}}+\alpha_{5} \mathrm{PPE}_{\mathrm{i}, \mathrm{t}}+\varepsilon_{\mathrm{i}, \mathrm{t}}
$$

Where $C F O_{i, t-1}$ is the operating cash flow. $P P E_{i, t}$ is the net property, plant, and equipment. Equation 4 is run for all samples (minimum of 10 firms) in the same industry each year to obtain the residual series for each firm. Then I use the standard deviation of the residual for year $t-4$ to year $t$ to proxy for accrual quality $\left(A Q_{i, t}\right)$. Next, I run the following regression to isolate the discretionary component from accrual quality.

$$
\mathrm{AQ}_{\mathrm{i}, \mathrm{t}}=\beta_{0}+\beta_{1} \operatorname{Ln}\left(\mathrm{AT}_{\mathrm{i}, \mathrm{t}}\right)+\beta_{2} \sigma\left(\mathrm{CFO}_{\mathrm{i}, \mathrm{t}}\right)+\beta_{3} \sigma\left(\mathrm{Sale}_{\mathrm{i}, \mathrm{t}}\right)+\beta_{4} \mathrm{Neg}_{\mathrm{i}, \mathrm{t}}+\varepsilon_{\mathrm{i}, \mathrm{t}}
$$

Where $A Q_{i, t}$ is accrual quality. $\sigma\left(C F O_{i, t}\right)$ is the standard deviation of operating cash flow, and $\sigma\left(\right.$ Sale $\left._{i, t}\right)$ is the standard deviation of sales. $\mathrm{Neg}_{i, t}$ is the percentage of year with negative earnings over the whole sample period. Therefore, the discretionary component from accrual quality (Disc_AQ) is the residual from Equation 5.

In line with previous literature, I choose both market-to-book value $(M B)$ and Tobin's $\mathrm{Q}$ (Tobin $Q$ ) to represent firm value. Tobin's $\mathrm{Q}$ in this study is defined as the ratio of enterprise value to book value.

\subsection{Baseline models}

I examine the colour effect on earnings management and firm value by performing regressions in which dependent variables are the proxies for earnings management and firm value. The independent variable involves the measure of colour effects and a number of other control variables suggested in the prior studies. Concretely, the following panel model is estimated to evaluate the association between the colour effect and earnings management/ firm value:

$$
\mathrm{DV}_{\mathrm{i}, \mathrm{t}}=\alpha_{0}+\alpha_{1} \mathrm{IV}_{\mathrm{i}, \mathrm{t}}+\alpha_{2} \mathrm{X}_{\mathrm{i}, \mathrm{t}}+\varepsilon_{\mathrm{i}, \mathrm{t}}
$$

Where $\mathrm{DV}_{\mathrm{i}, \mathrm{t}}$ represents PACDA,Disc_AQ, MB, or TobinQ. $\mathrm{IV}_{\mathrm{i}, \mathrm{t}}$ represents Colour, Number, or Simple. $\mathrm{X}_{\mathrm{i}, \mathrm{t}}$ is a set of relevant variables to control for differences in firm size, growth opportunities, liquidity, and agency problem. Specifically, I use market capitali- 
zation $(M V)$ and volatility $(\mathrm{Vol})$, defined as the standard deviation of daily returns, to capture the impact of firm size. The influence of agency problem, firm growth and liquidity are controlled through leverage (Lev), the number of years since IPO (IPO), and share prices (Prc), respectively. In light of Jaggi, Leung, Gul (2009), I use return on assets (ROA), market-to-book value $(M B)$, and turnover expressed in dollar $(T O)$ to explain earnings management. Similarly, I follow Green, Jame (2013) to control for the impact of return on equity $(R O E)$, payout ratio $(P O)$, and sales (Sale) in the regression for firm value. In order to avoid the compounding effect from the outliers, all variables are winsorized at $5 \%$ and $95 \%$ levels.

\section{Results and Discussion}

\subsection{Descriptive statistics}

Table 2 shows summary statistics of dependent, independent, and control variables for the period of 2000 to 2011. The mean (median) of absolute values of performance-adjusted current discretionary accruals is $0.064(0.006)$, which is smaller than that reported by Jaggi, Leung, Gul (2009) based on data in 1998-2000. It is somewhat attributable to a stricter and stricter regulation in Hong Kong over past 10 years. In terms of firm value, the average firm has a market-to-book ratio of 1.485 and a Tobin's $Q$ of -0.081 . If looking at independent variables, the sample firms are almost equally divided between warm and cool as the primary colour (51.5\% versus $48.5 \%$ ). Around $63 \%$ of samples just choose one colour and less than $40 \%$ companies use the recognizable number or character in their logos.

To further look into the colour effect, I conduct t-tests on equal means among dependent and control variables grouped by the colour dummies. Table 3 suggests that firms with warm logo colours seem to have less incentive to engage in earnings management $(P A C D A=0.060$ and Disc_AQ $=-0.005)$ and higher valuation $(M B=1.550$ and Tobin $Q$ $=0.094)$ compared to those with cool logo colours. Such differences are statistically significant at $5 \%$ or $1 \%$ levels. Similarly, samples with fewer colours and simpler logos yield a smaller PACDA and a bigger MB.

The correlation matrix of all variables is provided in Table 4. While the Pearson correlation coefficients are reported in the lower triangle, the Spearman correlation coefficients are presented in the upper triangle. As expected, the result reveals that both $P A C D A$ and Disc_AQ are negatively related to Colour, Number, and Simple, respectively. Most relationships are significant from a statistical perspective. These correlations indicate that earnings management is lower when the primary colour is warm, one colour is selected, and number or character is used inside the logo. The findings on $M B$ and Tobin $Q$ are consistent with the preceding conjecture as well.

In addition, Table 3 and Table 4 shows that the measures of colour effects appear correlated with certain firm characteristics, in particular market capitalization $(M V)$ and the number of year since IPO (IPO). Firms with warm logo colours tend to be larger and have a longer history in the capital market. To consider the potential impact of multicollinearnality, I would conduct additional tests in the robustness checks part. 
Table 2 | Descriptive Statistics

\begin{tabular}{|c|c|c|c|c|c|c|}
\hline & Obs. & Mean & Median & S.D. & Min & Max \\
\hline \multicolumn{7}{|c|}{ Dependent Variables } \\
\hline PACDA & 6,309 & 0.064 & 0.006 & 0.140 & 0.000 & 0.556 \\
\hline Disc_AQ & 5,148 & -0.005 & -0.007 & 0.017 & -0.030 & 0.043 \\
\hline$M B$ & 9,403 & 1.485 & 0.960 & 1.465 & 0.110 & 5.760 \\
\hline TobinQ & 9,007 & -0.081 & 0.011 & 1.177 & -3.199 & 2.424 \\
\hline \multicolumn{7}{|c|}{ Independent Variables } \\
\hline Colour & 10,213 & 0.515 & 1.000 & 0.500 & 0.000 & 1.000 \\
\hline Number & 10,203 & 0.634 & 1.000 & 0.482 & 0.000 & 1.000 \\
\hline Simple & 10,208 & 0.383 & 0.000 & 0.486 & 0.000 & 1.000 \\
\hline \multicolumn{7}{|c|}{ Control Variables } \\
\hline$M V$ & 9,516 & 0.472 & 0.069 & 0.965 & 0.005 & 3.821 \\
\hline Vol & 10,209 & 0.039 & 0.035 & 0.019 & 0.014 & 0.083 \\
\hline Lev & 9,987 & 0.043 & 0.014 & 0.277 & -0.600 & 0.437 \\
\hline IPO & 10,213 & 14.608 & 14.000 & 6.907 & 1.000 & 26.000 \\
\hline Prc & 9,516 & 4.100 & 1.130 & 7.325 & 0.092 & 30.950 \\
\hline$R O A$ & 9,905 & 0.052 & 0.073 & 0.152 & -0.363 & 0.306 \\
\hline TO & 9,355 & 0.194 & 0.040 & 0.334 & 0.001 & 1.236 \\
\hline ROE & 9,610 & 0.038 & 0.079 & 0.253 & -0.670 & 0.504 \\
\hline PO & 9,965 & 0.182 & 0.061 & 0.222 & 0.000 & 0.690 \\
\hline Sale & 9,990 & 0.315 & 0.065 & 0.613 & 0.001 & 2.400 \\
\hline
\end{tabular}

Note: Table 2 reports the time-series average of annual cross-sectional descriptive statistics which involve the number of observation (Obs.), mean, median, standard deviation (S.D.), minimum (Min), and maximum (Max). The sample employed in this study is just restricted to firms with logo. The observations are winsorized at $5 \%$ and $95 \%$ levels. PACDA is the absolute value of performance-adjusted current discretionary accruals (Kothari, Leone, Wasley, 2005), scaled by lagged total assets. Disc_AQ is the discretionary component of accruals quality following Francis, LaFond, Olsson, Schipper, (2005). MB is the ratio of the firms' market value of equity to book value of equity. TobinQ is the ratio of the enterprise value (market value of equity plus debt) to book value (book value of equity plus debt. Colour is equal to 1 if samples with major logo colours to be brown, orange, purple, red, or yellow, otherwise 0 . Number is equal to 1 if the number of colour used in the logo is one, otherwise 0 . Simple is equal to 1 if character or number appears in the logo, otherwise $0 . M V$ is the market capitalization. $\mathrm{Vol}$ is the standard deviation of daily returns over a given year. Lev is the ratio of total debt over total assets. IPO is the number of years since a firm's IPO. Prc is the share price. $R O A$ is the ratio of net income before extraordinary items to total assets. $T O$ is the average daily turnover expressed in dollar over the 12 months in the year. $R O E$ is the ratio of net income before extraordinary items to book value of equity. $P O$ is the sum of dividends and repurchases over net income. Sale is the total sale. 


\begin{tabular}{|c|c|c|c|c|c|c|c|c|c|}
\hline & \multicolumn{3}{|c|}{ Colour } & \multicolumn{3}{|c|}{ Number } & \multicolumn{3}{|c|}{ Simple } \\
\hline & 0 & 1 & t-value & 0 & 1 & t-value & 0 & 1 & t-value \\
\hline \multicolumn{10}{|c|}{ Dependent Variables } \\
\hline PACDA & 0.068 & 0.060 & $2.211^{* *}$ & 0.069 & 0.061 & $2.095^{* *}$ & 0.070 & 0.061 & $2.628^{* * *}$ \\
\hline Disc_AQ & -0.004 & -0.005 & $2.480^{* *}$ & -0.004 & -0.005 & $2.597^{* *}$ & -0.005 & -0.005 & $2.371^{* *}$ \\
\hline MB & 1.426 & 1.550 & $4.089^{* * *}$ & 1.444 & 1.558 & $3.650^{* * * *}$ & 1.464 & 1.520 & $2.828^{* * * *}$ \\
\hline TobinQ & 0.069 & 0.094 & $2.026^{* *}$ & 0.063 & 0.112 & $2.904^{* * * *}$ & 0.048 & 0.137 & $3.493^{* * * *}$ \\
\hline \multicolumn{10}{|c|}{ Control Variables } \\
\hline$M V$ & 0.437 & 0.504 & $3.358^{* * *}$ & 0.468 & 0.474 & $0.268^{* *}$ & 0.541 & 0.359 & $8.970^{* * * *}$ \\
\hline Vol & 0.039 & 0.039 & 1.583 & 0.040 & 0.039 & $3.610^{* * * *}$ & 0.038 & 0.041 & $7.483^{* * * *}$ \\
\hline Lev & 0.045 & 0.040 & 0.892 & 0.051 & 0.038 & $2.209^{* *}$ & 0.021 & 0.078 & $10.004^{* * * *}$ \\
\hline IPO & 13.843 & 15.329 & $10.927^{* * * *}$ & 13.851 & 15.042 & $8.421^{* * * *}$ & 15.015 & 13.955 & $7.565^{* * * *}$ \\
\hline Prc & 3.843 & 4.337 & $3.294^{* * * *}$ & 4.162 & 4.064 & 0.627 & 4.505 & 3.437 & $6.926^{* * * *}$ \\
\hline$R O A$ & 0.057 & 0.048 & $3.178^{* * *}$ & 0.052 & 0.053 & 0.222 & 0.051 & 0.054 & 0.844 \\
\hline Tо & 1.849 & 2.024 & $2.522^{* *}$ & 2.041 & 1.880 & $2.242^{* *}$ & 2.088 & 1.699 & $5.476^{* * *}$ \\
\hline ROE & 0.044 & 0.033 & $2.282^{* *}$ & 0.031 & 0.043 & $2.276^{* *}$ & 0.039 & 0.037 & 0.355 \\
\hline PO & 0.180 & 0.183 & 0.633 & 0.168 & 0.190 & $4.612^{* * * *}$ & 0.190 & 0.168 & $4.729^{* * *}$ \\
\hline Sale & 0.302 & 0.326 & $1.973^{* *}$ & 0.315 & 0.314 & 0.091 & 0.345 & 0.266 & $6.242^{* * *}$ \\
\hline
\end{tabular}

Note: Table 3 reports the time-series average of annual cross-sectional dependent variables and control variables by colour measures (Colour, Number, and Simple) and their equality tests. The sample employed in this study is just restricted to firms with logo. The observations are winsorized at $5 \%$ and $95 \%$ levels . Variable definitions are in Table $2 .{ }^{* * *},{ }^{* *}$, and ${ }^{*}$ indicate significance at the $1 \%, 5 \%$, and $10 \%$ levels, respectively. 


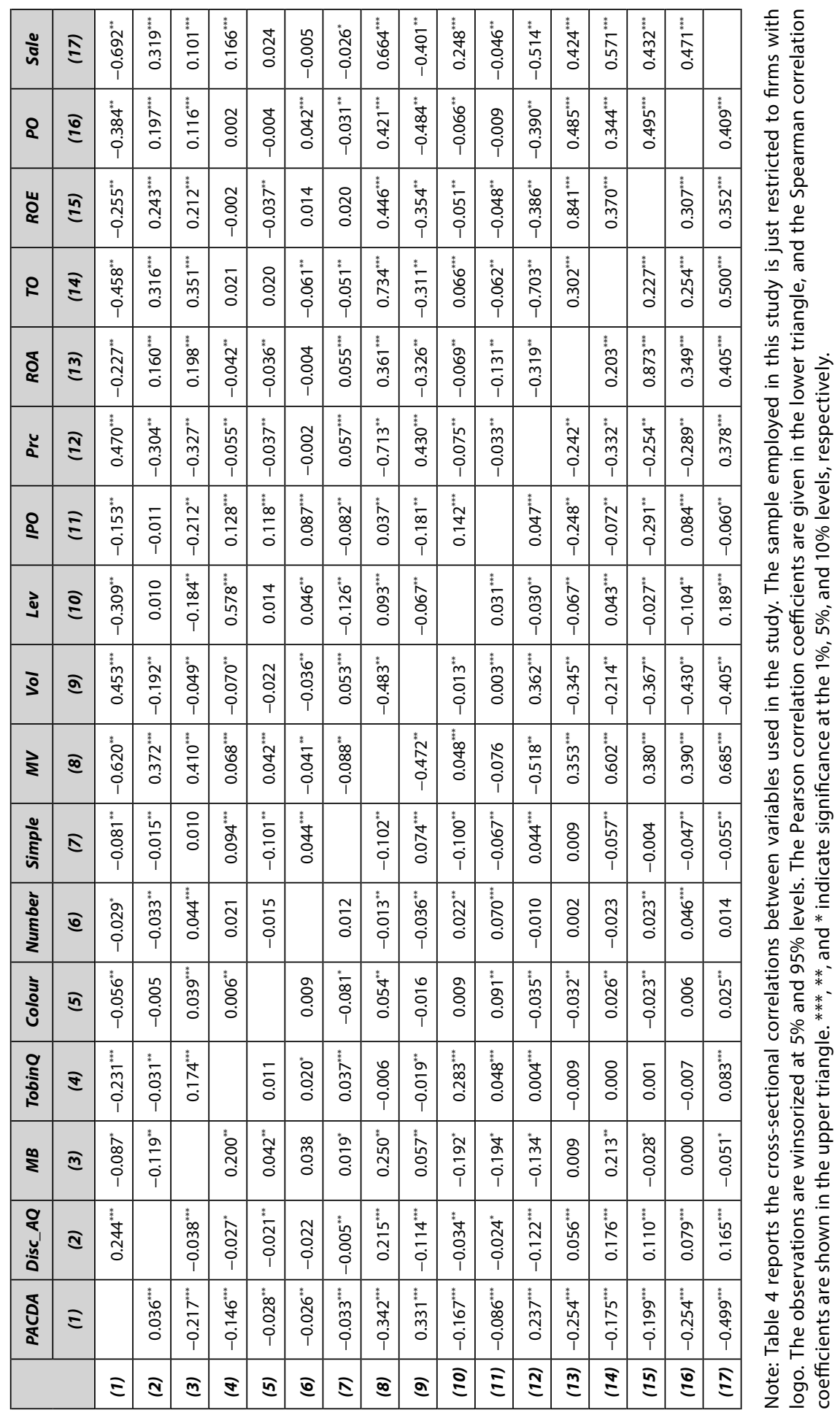




\subsection{Multivariate analysis}

\subsubsection{Colour effects and earnings management}

I perform panel regressions of absolute values of performance-adjusted current discretionary accruals $(P A C D A)$ and discretionary component of accrual quality (Disc_AQ) as proxies for earnings management on the colour effect measure. The result is reported in Table 5. Columns (1)-(3) indicate that the coefficients on Colour, Number, and Simple are negative and statistically significant at the $5 \%$ level, implying that firms with warm colours as a major logo colour, fewer colours used in the logo, and recognizable elements in the logo are associated with lower earnings management.

The findings on Colour are in line with Madden, Hewett and Roth (2000) and Maier, Barchfeld, Elliot and Pekrun (2009), suggesting that warm colours can spark investor interests in financial statements. If investors spend more effort in understanding the annual reports carefully and comprehensively, firms are less likely to engage in earnings management. In a nutshell, this supports my hypothesis $\mathrm{H} 1$ that there is a negative association between warm logo colour and earnings management. Moreover, the results on Number and Simple are consistent with the argument that simpler logos are easier to be accepted by investors via the channel of perceptual fluency (Bottomley, Doyle, 2006; Green, Jame, 2013). The results using discretionary component of accrual quality (Disc_AQ) as the dependent variable are qualitatively the same.

Table 5 | Colour and Earnings Management

\begin{tabular}{|c|c|c|c|c|c|c|}
\hline & \multicolumn{3}{|c|}{ PACDA } & \multicolumn{3}{|c|}{ Disc_AQ } \\
\hline & (1) & (2) & (3) & (4) & (5) & (6) \\
\hline Colour & $-0.007^{* *}$ & & & $-0.007^{* *}$ & & \\
\hline Number & & $-0.031^{* *}$ & & & $-0.005^{* *}$ & \\
\hline Simple & & & $-0.076^{* * * *}$ & & & $-0.005^{* *}$ \\
\hline $\operatorname{Ln}(M V)$ & $-0.214^{* * *}$ & $-0.214^{* * *}$ & $-0.215^{* * *}$ & $-0.012^{* * *}$ & $-0.012^{* * *}$ & $-0.012^{* * *}$ \\
\hline Vol & $7.480^{* * * *}$ & $7.470^{* * * *}$ & $7.500^{* * *}$ & 0.033 & 0.036 & 0.037 \\
\hline$R O A$ & $-0.715^{* * *}$ & $-0.716^{* * *}$ & $-0.711^{* * *}$ & $-0.033^{* *}$ & $-0.033^{* *}$ & $-0.032^{* *}$ \\
\hline Lev & $-0.643^{* * *}$ & $-0.643^{* * *}$ & $-0.649^{* * *}$ & -0.007 & $-0.008^{* * *}$ & -0.008 \\
\hline $\operatorname{Ln}(I P O)$ & $-0.106^{* *}$ & $-0.102^{* *}$ & $-0.108^{* *}$ & -0.005 & -0.005 & -0.005 \\
\hline$M B$ & $-0.188^{* * *}$ & $-0.188^{* * *}$ & $-0.188^{* * *}$ & -0.002 & $-0.002^{* * *}$ & -0.002 \\
\hline 1/Prc & 0.007 & 0.006 & 0.006 & 0.002 & $0.002^{*}$ & 0.002 \\
\hline $\operatorname{Ln}(T O)$ & 0.019 & 0.006 & 0.018 & $0.004^{* *}$ & $0.004^{* * *}$ & $0.004^{* *}$ \\
\hline Adj $R^{2}$ & 0.280 & 0.280 & 0.280 & 0.050 & 0.049 & 0.049 \\
\hline Wald $X^{2}$ & 925.04 & 926.04 & 928.84 & 80.72 & 79.38 & 79.40 \\
\hline Obs & 5,919 & 5,919 & 5,919 & 4,830 & 4,828 & 4,828 \\
\hline No. of Group & 1,046 & 1,046 & 1,046 & 1,019 & 1,019 & 1,019 \\
\hline
\end{tabular}

Note: Table 5 reports the estimates from panel regressions with random effects of earnings management measures on colour measures and other characteristics. The sample employed in this study is just restricted to firms with logo. The observations are winsorized at $5 \%$ and $95 \%$ levels. Variable definitions are in Table 2. Standard errors are clustered by firms. ${ }^{* * *},{ }^{* * *}$, and ${ }^{*}$ indicate significance at the $1 \%, 5 \%$, and $10 \%$ levels, respectively. 


\subsubsection{Colour effects and firm value}

To evaluate the impact of colour effects on firm value, I follow the baseline model and repeat similar analyses. Table 6 reports the results of the panel regression. The first column shows that $M B$ is positive and significantly related to Colour. Specifically, the warm logo colour would translate into an additional 0.097 in the market-to-book ratio. Besides, other two measures (Number and Simple) are significantly and positively associated with the market-to-book ratio. Not surprisingly, I find a similar relation between the colour effect measure and Tobin's Q with reference to columns (4)-(6) in Table 6. Tobin's Q is 0.149 higher for companies that choose than those that do not choose warm colours as the primary colour to fill in their logos. Overall, the results provide strong evidence in favour of $\mathrm{H} 2$.

Table 6 | Colour and Firm Value

\begin{tabular}{|c|c|c|c|c|c|c|}
\hline & \multicolumn{3}{|c|}{$M B$} & \multicolumn{3}{|c|}{ TobinQ } \\
\hline & (1) & (2) & (3) & (4) & (5) & (6) \\
\hline Colour & $0.097^{* * * *}$ & & & $0.149^{* *}$ & & \\
\hline Number & & $0.051^{* *}$ & & & $0.398^{* *}$ & \\
\hline Simple & & & $0.075^{* *}$ & & & $0.305^{* *}$ \\
\hline $\operatorname{Ln}(M V)$ & $0.478^{* * * * *}$ & $0.477^{* * * *}$ & $0.479^{* * *}$ & $0.551^{* * * *}$ & $0.545^{* * * *}$ & $0.560^{* * * *}$ \\
\hline Vol & $8.203^{* * * *}$ & $8.148^{* * * *}$ & $8.132^{* * *}$ & 8.955 & 9.169 & 9.096 \\
\hline ROE & $0.003^{* * * *}$ & $0.003^{* * * *}$ & $0.003^{* * *}$ & $0.017^{* * * *}$ & $0.016^{* * * *}$ & $0.017^{* * * *}$ \\
\hline Lev & $0.580^{* * * *}$ & $0.580^{* * * *}$ & $0.572^{* * * *}$ & $11.923^{* * *}$ & $11.908^{* * * *}$ & $11.877^{* * *}$ \\
\hline PO & $-0.002^{* * *}$ & $-0.002^{* * * *}$ & $-0.002^{* * * *}$ & -0.004 & -0.003 & -0.003 \\
\hline $\operatorname{Ln}(I P O)$ & $-0.262^{* * *}$ & $-0.273^{* * * *}$ & $-0.267^{* * * *}$ & -0.300 & -0.282 & -0.290 \\
\hline Ln(Sale) & $-0.260^{* * *}$ & $-0.260^{* * *}$ & $-0.261^{* * *}$ & $-0.396^{* * * *}$ & $-0.393^{* * *}$ & $-0.397^{* * *}$ \\
\hline 1/Prc & 0.081 & 0.081 & 0.081 & $0.129^{* *}$ & $0.132^{* *}$ & $0.129^{* *}$ \\
\hline Adj $R^{2}$ & 0.198 & 0.196 & 0.197 & 0.087 & 0.087 & 0.087 \\
\hline Wald $X^{2}$ & $2,564.47$ & $2,553.72$ & $2,558.08$ & 602.87 & 603.75 & 603.40 \\
\hline Obs. & 8,948 & 8,947 & 8,950 & 8,899 & 8,898 & 8,901 \\
\hline \# of Group & 1,314 & 1,314 & 1,314 & 1,307 & 1,307 & 1,307 \\
\hline
\end{tabular}

Note: Table 6 reports the estimates of panel regressions with random effects of firm value measures on colours measures and other characteristics. MB is the ratio of the firms' market value of equity to book value of equity. The sample employed in this study is just restricted to firms with logo. The observations are winsorized at $5 \%$ and $95 \%$ levels. Variable definitions are in Table 2 . Standard errors are clustered by firms. ${ }^{* * * * * *}$, , and ${ }^{*}$ indicate significance at the $1 \%, 5 \%$, and $10 \%$ levels, respectively. 


\subsection{Robustness checks}

To account for other potential factors that may drive above findings, I run additional tests to check the robustness of colour effects on earnings management and firm value. For the sake of brevity, I only tabulate the coefficient estimates on key variables (Colour, Number, and Simple) in Table 7.

In Panel A, I run the estimation on the baseline model by the Fama-Macbeth (1973) approach. Specifically, I conduct cross-sectional regressions each year and then take the average of the estimated coefficients across years. The Newey-West (1987) standard errors are used to examine the significance of estimates. As shown in Panel A, the Fama-Macbeth methodology yields similar results with only slightly different in magnitudes.

I note that the colour effect measure is related to $M V$ and $I P O$ in the correlation matrix shown in Table 4. To mitigate the impact of multicollinearnality among independent variables, I follow Green, Jame (2013) to adjust the dependent variables (PACDA, Disc $A Q, M B$, and Tobin $Q$ ) using $M V$ and $I P O$ before running the panel regression. Firstly, the samples are divided into five quintiles according to $M V$ at the end of each year. Next, within each size quintile, samples are further partitioned into five quintiles according to $I P O$ to generate 25 portfolios. Finally, I use each equally-weighted average of these portfolios to adjust $P A C D A, D i s c \_A Q, M B$, and Tobin $Q$ in each portfolio, respectively. The panel regression relying on the adjusted dependent variable in Panel B suggests that the coefficients on Colour, Number, and Simple maintain essentially unchanged after removing the effect of muliticollinearnality.

Due to the different nature of financial industries, the results are likely to be biased if these firms are included. Therefore, I drop all financial firms and conduct the analyses again. The results in Panel C show that the coefficients on Colour, Number, and Simple variables quantitatively resemble to prior results, suggesting that my findings are not driven by financial companies.

To address whether the result is sensitive to the winsorizing value, I repeat the regression on the baseline model but winsorize all variables at $1 \%$ and $99 \%$ levels. As shown in Panel D, the findings continue to hold valid.

The next robustness check involves the inclusion of industry dummies in the panel regression. The industry classification code comes from Datastream, where there are a total of 39 industries. I add a more detailed industry classification to re-estimate the regression. The results in Panel E remain consistent with the main findings in Table 5 and Table 6 implying that they are not affected by the industry effect.

There are firms that altered their logo colours during the sample period. By looking into within-firm variation, I further verify that companies with warm logo colours (one logo colour used, and simple logos) are systematically different from companies with cool logo colours (more than one colour used, and complex logos). In this sense, I run the panel regressions for the full samples of altering colour in the logo. The major result in Panel $\mathrm{F}$ is that changes in logo colours are negatively and positively related to changes in earnings management and firm value, respectively. By the same token, the economic magnitudes are quantitatively similar to the between-firm estimates from the panel regressions. As a whole, the finding on the colour change is conducive to mitigating my worry that the between-firm estimates are caused by omitted variables. 
Table 7 | Robustness Checks

\begin{tabular}{|c|c|c|c|c|}
\hline & PACDA & Disc_AQ & MB & TobinQ \\
\hline \multicolumn{5}{|c|}{ Panel A: Fama-MacBeth Approach } \\
\hline Colour & $-0.029^{*}$ & $-0.689^{* * *}$ & $0.135^{* * *}$ & $0.003^{* *}$ \\
\hline Number & $-0.437^{* * *}$ & $-0.213^{* * *}$ & $0.003^{*}$ & $0.685^{* * *}$ \\
\hline Simple & $-0.494^{* * *}$ & $-0.674^{* * *}$ & $0.080^{* * *}$ & $0.627^{* * *}$ \\
\hline \multicolumn{5}{|c|}{ Panel B: MV/IPO Adjusted Estimates } \\
\hline Colour & $-0.096^{* *}$ & $-0.728^{* * *}$ & $0.696^{* * *}$ & $0.069^{* *}$ \\
\hline Number & $-0.364^{* * *}$ & $-0.291^{* *}$ & $0.366^{* * *}$ & $0.365^{* * *}$ \\
\hline Simple & $-0.939^{* * *}$ & $-0.634^{* * *}$ & $0.745^{* * *}$ & $0.356^{* * *}$ \\
\hline \multicolumn{5}{|c|}{ Panel C: Drop Financials } \\
\hline Colour & $-0.309^{* *}$ & $-0.540^{* * *}$ & $0.135^{* * *}$ & $0.140^{* *}$ \\
\hline Number & $-0.737^{* * *}$ & $-0.533^{* *}$ & $0.059^{* * *}$ & $0.484^{* * *}$ \\
\hline Simple & $-0.500^{* * *}$ & $-0.536^{* *}$ & $0.085^{* * *}$ & $0.463^{* * *}$ \\
\hline \multicolumn{5}{|c|}{ Panel D: Winsorize at $1 \%$ and $99 \%$ levels } \\
\hline Colour & $-0.181^{* *}$ & $-0.115^{* * *}$ & $0.143^{* * *}$ & $0.250^{* *}$ \\
\hline Number & $-0.115^{* *}$ & $-0.025^{* *}$ & $0.005^{*}$ & $0.805^{* * *}$ \\
\hline Simple & $-0.129^{* *}$ & $-0.064^{* *}$ & $0.030^{* *}$ & $0.118^{* *}$ \\
\hline \multicolumn{5}{|c|}{ Panel E: Include Industry Dummies } \\
\hline Colour & $-0.097^{* *}$ & $-0.118^{* *}$ & $0.521^{* * * *}$ & $0.015^{*}$ \\
\hline Number & $-0.158^{* *}$ & $-0.463^{* *}$ & $0.690^{* * *}$ & $0.295^{* * *}$ \\
\hline Simple & $-0.812^{* * *}$ & $-0.622^{* * *}$ & $0.369^{* * *}$ & $0.087^{* *}$ \\
\hline \multicolumn{5}{|c|}{ Panel F: Color-Altering Samples } \\
\hline Colour & $-0.108^{* * * *}$ & $-0.091^{* * *}$ & $0.047^{* *}$ & $0.047^{* *}$ \\
\hline Number & $-0.176^{* * *}$ & $-0.007^{*}$ & $0.060^{* *}$ & $0.044^{* *}$ \\
\hline Simple & $-0.184^{* * *}$ & $-0.206^{* * *}$ & $0.361^{* * *}$ & $0.142^{* * *}$ \\
\hline \multicolumn{5}{|c|}{ Panel G: Endogeneity Test } \\
\hline Colour & $-0.008^{*}$ & $-0.615^{* *}$ & $0.729^{* * *}$ & $0.604^{* *}$ \\
\hline Number & $-0.070^{* *}$ & $-0.661^{* * *}$ & $0.127^{* * *}$ & $0.140^{* * * *}$ \\
\hline Simple & $-0.245^{* * *}$ & $-0.196^{* *}$ & $0.322^{* * *}$ & $0.211^{* * *}$ \\
\hline
\end{tabular}

Note: Table 7 reports the results of variations on the panel regression in Table 5 and Table 6 . The sample employed in this study is just restricted to firms with logo. The dependent variables include the absolute value of performance-adjusted current discretionary accruals $(P A C D A)$, the discretionary component of accruals quality (Disc_AQ), the ratio of the firms' market value of equity to book value of equity $(M B)$, and the ratio of the enterprise value to book value (Tobin's $Q$ ). For simplicity, the estimated coefficients are tabulated for independent variables concerned (Colour, Number, and Simple). Panel A shows the results after using the Fama-MacBeth (1973) approach. Panel B shows the results where dependent variables are adjusted after demeaning from one of 25 benchmark portfolios sorted on $M V$ and IPO. Panel $C$ shows the results after eliminating financial companies. Panel $D$ shows the results after winsorizing the sample at the $1^{\text {st }}$ instead of $5^{\text {th }}$ percentile. Panel $\mathrm{E}$ shows the results after considering the industry effect. Panel $\mathrm{F}$ shows the results on samples with logo colour change in the study period. Panel $G$ shows the results on endogeneity test by the simultaneous equation system. ${ }^{* * *},{ }^{* *}$, and ${ }^{*}$ indicate significance at the $1 \%, 5 \%$, and $10 \%$ levels, respectively. 
The final check is to examine whether the result is driven by the endogeneity problem. It seems plausible that the colour used in the company logo is also affected by earnings management and firm value, because both of them should be one of the factors considered by the manager to design the logo. To mitigate the endogeneity, I repeat the analysis by the simultaneous equation system. In terms of the relationship between colours and earnings management, the colour equation is specified in the system as follows: $I V_{t}=f\left(D V_{t}, \operatorname{Ln}(M V)\right.$, Vol, ROE, Lev, PO, Ln(IPO), Ln(Sale ), 1/Prc). With respect to the association between colours and firm value, the colour equation is specified in the system as follows: $\mathrm{IV}_{\mathrm{t}}=\mathrm{f}\left(\mathrm{DV}_{\mathrm{t}}, \mathrm{Ln}(\mathrm{MV})\right.$, Vol, ROA, Lev, $\left.\operatorname{Ln}(\mathrm{IPO}), 1 / \operatorname{Prc}, \mathrm{Ln}(\mathrm{TO})\right)$.Panel $\mathrm{F}$ indicates that the results remain the same as before.

\section{Conclusion}

I analysed the association between logo colour effects and earnings management and firm value. Overall, the results provide evidence that firms having warm colours as a major logo colour, fewer colours used in the logo, and recognizable elements in the logo are associated with lower level of earnings management, thus leading to higher firm value. This implies that logos with a warm colour and simple design could attract investors' attention to look through the whole financial document prudently, which deters managers from manipulating the reported earnings and improves firm value. Moreover, my findings are robust to different estimation methods, multicollinearnality, sample bias, outliers, industry effects, colour-changing samples, and endogeneity.

Similar to other studies, this paper is subject to several limitations. First, the validity of the results relies on proxies for earnings management and firm value. Second, although I use three measures to capture the logo colour effect, the validity of the results is also subject to proper measurement of colours. Finally, my conclusion is drawn based on samples in Hong Kong, and caution should be exercised to generalize these results.

\section{Reference}

Abrahamson, E., Amir, E. (1996). The Information Content of the President's Letter to Shareholders. Journal of Business Finance and Accounting, 23(8), 1157-1182. http://dx.doi.org/10.1111/j.1468-5957.1996.tb01163.x

Bansal, P., Clelland, I. (2004). Talking Trash: Legitimacy, Impression Management, and Unsystematic Risk in the Context of the Natural Environment. Academy of Management Journal, 47(1), 93-103, http://dx.doi.org/10.2307/20159562

Benbasat, I., Dexter, A. (1985). An Experimental Evaluation of Graphical and Color-Enhanced Information Presentation. Management Science, 31(11), 1348-1364, http://dx.doi.org/10.1287/mnsc.31.11.1348

Benbasat, I., Dexter, A. (1986). An Investigation of the Effectiveness of Color and Graphical Information Presentation under Varying Time Constraints. MIS Quarterly, 10(1), 59-83, http://dx.doi.org/10.2307/248881

Bottomley P., Doyle, J. (2006). The Interactive Effects of Colors and Products on Perceptions of Brand Logo Appropriateness. Marketing Theory, 6(1), 63-83, http://dx.doi. org/10.1177/1470593106061263

Bowen, R., Davis, A., Matsumoto, D. (2005). Emphasis on Pro Forma versus GAAP Earnings in Quarterly Press Releases: Determinants, SEC Intervention and Market Reactions. Accounting Review, 80(4), 1011-1038, http://dx.doi.org/10.2308/accr.2005.80.4.1011 
Chaney, P., Lewis, C. (1995). Earnings Management and Firm Valuation under Asymmetric Information. Journal of Corporate Finance, 1(3-4), 319-345, http://dx.doi.org/10.1016/09291199(94)00008-I

Chebat, J., Morrin, M. (2007). Colors and Cultures: Exploring the Effects of Mall Décor on Consumer Perceptions. Journal of Business Research, 60(3), 189-196, http://dx.doi.org/10.1016/j.jbusres.2006.11.003

Clatworthy, M., Jones, M. (2003). Financial Reporting of Good and Bad News: Evidence from Accounting Narratives. Accounting and Business Research, 33(3), 171-185, http://dx.doi.org/10.1080/00014788.2003.9729645

Courtis, J. (2004). Color as Visual Rhetoric in Financial Reporting. Accounting Forum, 28(3), 265-281, http://dx.doi.org/10.1016/j.accfor.2004.07.003

Elsbach, K., Sutton, R. (1992). Acquiring Organizational Legitimacy through Illegitimate Actions: A Marriage of Institutional and Impression Management Theories. Academy of Management Journal, 35(4), 699-738, http://dx.doi.org/10.2307/256313

Fama, E., MacBeth, J. (1973). Risk, Return, and Equilibrium: Empirical Tests. Journal of Political Economy, 81(3), 607-636, http://dx.doi.org/10.1086/260061

Francis, J., LaFond, R., Olsson, P., Schipper, K. (2005). The Market Pricing of Accruals Quality. Journal of Accounting and Economics, 39(2), 295-327, http://dx.doi.org/10.1016/j. jacceco.2004.06.003

Green, T., Jame, R. (2013). Company Name Fluency, Investor Recognition, and Firm Value. Journal of Financial Economics, 109(3), 813-834, http://dx.doi.org/10.1016/j.jfineco.2013.04.007

Hooghiemstra, R. (2010). Letters to the Shareholders: A Content Analysis Comparison of Letters Written by CEOs in the United States and Japan. International Journal of Accounting, 45(3), 275-300, http://dx.doi.org/10.1016/j.intacc.2010.06.006

Jaggi, B., Leung, S., Gul, F. (2009). Family Control, Board Independence and Earnings Management: Evidence Based on Hong Kong Firms. Journal of Accounting and Public Policy, 28(4), 281-300, http://dx.doi.org/10.1016/j.jaccpubpol.2009.06.002

Kothari, S., Leone, A., Wasley, C. (2005). Performance Matched Discretionary Accrual Measures. Journal of Accounting and Economics, 39(1), 163-197, http://dx.doi.org/10.1016/j. jacceco.2004.11.002

Krische, S. (2005). Investors' Evaluations of Strategic Prior-Period Benchmark Disclosures in Earnings Announcements. Accounting Review, 80(1), 243-268, http://dx.doi.org/10.2308/ accr.2005.80.1.243

Lambert, R. (2001). Contracting Theory and Accounting. Journal of Accounting and Economics, 32(1-3), 3-87, http://dx.doi.org/10.1016/S0165-4101(01)00037-4

Leary, M., Kowalski, R. (1990). Impression Management: A Literature Review and Two-Component Model. Psychological Bulletin, 107(1), 34-47, http://dx.doi.org/10.1037/0033-2909.107.1.34

Madden, T., Hewett, K., Roth, M. (2000). Managing Images in Different Cultures: A Cross-National Study of Color Meanings and Preferences. Journal of International Marketing, 8(4), 90-107, http://dx.doi.org/10.1509/jimk.8.4.90.19795

Maier, M., Barchfeld, P., Elliot, A., Pekrun, R. (2009). Context Specificity of Implicit Preferences: The Case of Human Preference for Red. Emotion, 9(5), 734-738, http://dx.doi.org/10.1037/ a0016818

Merkl-Davies, D., Brennan, N. (2007). Discretionary Disclosure Strategies in Corporate Narratives: Incremental Information or Impression Management? Journal of Accounting Literature, 26, 116-194. Available at: http://hdl.handle.net/10197/2907 
Muino, F., Trombetta, M. (2009). Does Graph Disclosure Bias Reduce the Cost of Equity Capital? Accounting and Business Research, 39(2), 83-102, http://dx.doi.org/10.1080/00014788.2009. 9663351

Newey, W., West, K. (1987). A Simple Positive Definite Heteroskedasticity and Autocorrelation Consistent Covariance Matrix. Econometrica, 55(3), 703-708, http://dx.doi.org/10.2307/1913610

Ogden, S., Clarke, J. (2005). Customer Disclosures, Impression Management and the Construction of Legitimacy: Corporate Reports in the UK Privatized Water Industry. Accounting, Auditing and Accountability Journal, 18(3), 313-345, http://dx.doi.org/10.1108/09513570510600729

Osma, B., Guillamon-Saorin, E. (2011). Corporate Governance and Impression Management in Annual Results Press Release. Accounting, Organizations and Society, 36(4-5), 187-208.

Schrand, C., Walther, B. (2000). Strategic Benchmarks in Earnings Announcements: The Selective Disclosure of Prior-Period Earnings Components. Accounting Review, 75(2), 151-177, http://dx.doi.org/10.2308/accr.2000.75.2.151

Shleifer, A. (1986). Do Demand Curves for Stocks Slope Down? Journal of Finance, 41(3), 579-590, http://dx.doi.org/10.1111/j.1540-6261.1986.tb04518.x

Smith, M., Taffler, R. (1992). Readability and Understandability: Different Measures of the Textual Complexity of Accounting Narrative. Accounting, Auditing and Accountability Journal, 5(4), 84-98, http://dx.doi.org/10.1108/09513579210019549 